\title{
Molecular analysis of a California strain of Rupestris stem pitting-associated virus isolated from declining Syrah grapevines
}

\author{
Brief Report \\ M. F. Lima ${ }^{1}$, R. Alkowni ${ }^{1}$, J. K. Uyemoto ${ }^{2}$, D. Golino ${ }^{1}$, \\ F. Osman ${ }^{1}$, and A. Rowhani ${ }^{1}$ \\ ${ }^{1}$ Department of Plant Pathology, University of California, Davis, California, U.S.A. \\ ${ }^{2}$ USDA-ARS, University of California, Davis, California, U.S.A.
}

Received August 4, 2005; accepted February 8, 2006

Published online March 20, 2006 (C) Springer-Verlag 2006

Summary. The sequence of the genome of a Rupestris stem pitting-associated virus (RSPaV) isolated from a declining Syrah grapevine in California, designated the Syrah strain (RSPaV-SY) was determined. The genome of this strain had an overall nucleotide identity of $77 \%$ in comparison with RSPaV sequences in GenBank; the coat protein was the most conserved gene among RSPaV sequences and the replicase was the least conserved gene. Phylogenetic analysis of partial coat protein and replicase gene sequences showed RSPaV-SY clustered independently from the majority of RSPaV isolates.

Rupestris stem pitting (RSP) is one disease in the rugose wood disease complex of grapevines [2]. The other diseases are corky bark, Kober stem grooving, and LN33 stem grooving [4]. RSP is characterized by pitting symptoms below inoculum chips in St. George grapevines (Vitis rupestris Steele). Chronic infections produce stunting and slow decline [3]. The virus associated with the disease is Rupestris stem pitting-associated virus ( $\mathrm{RSPaV})$, which is a member of the genus Foveavirus [5] in the family Flexiviridae [1]. RSPaV is restricted to grapevines, is not mechanically transmissible [5], and is not known to spread naturally. The virus is found in pollen grains [9] and seeds [10], but these sources do not give rise to infected seedlings [6]. The objectives of this study were to sequence the genome of a strain of RSPaV isolated from a diseased Syrah grapevine (RSPaV-SY) and to use it for sequence comparisons with other RSPaV strains and for design of specific primers to assay field collections for the presence of this virus strain.
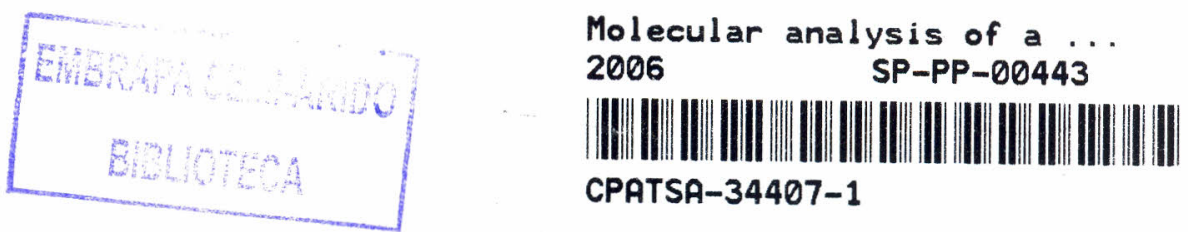
The source of RSPaV-SY was a field selection of $V$. vinifera L. variety Syrah exhibiting weak growth and red canopy with an enlarged scion trunk immediately above the graft union. Prior to sacrificing the grape plant, canes were collected and two-node cuttings were rooted and maintained in a greenhouse as source plants. Extracts of leaf petioles were tested for RSPaV, grapevine leaf roll-associated viruses $-1,-2,-2$ redglobe, $-3,-4,-5,-7$, and -9 ; grapevine viruses $-A,-B$, and -D; grapevine fanleaf virus, Arabis mosaic virus, and tomato ringspot virus in a onestep RT-PCR assay [9]; only RSPaV was identified.

Double-stranded RNA was purified from bark tissues and leaf petioles [11] and a dsRNA of ca. $8.7 \mathrm{kbp}$ in size was detected, which was used to construct a cDNA library [12]. Complementary DNA clones were d(A) tailed [13] and cloned into the Topo TA cloning vector (Invitrogen-Life Technologies). Selected clones were sequenced on both sense and anti-sense strands using vector primers T7 and T3. Existing gaps were completed using specific PCR primers designed based on known nucleotide sequences. The $5^{\prime}$ and $3^{\prime}$ terminal sequences were obtained using a $5^{\prime}$ rapid amplification of cDNA ends kit (Invitrogen-Life Technologies) and RT-PCR with oligo d(T)-priming, respectively. Sequence data were analyzed using the BLAST program of the National Center for Biotechnology Information (NCBI). For primer design and ORF search, the DNAsis Max Program package version 2.0 (Hitachi software Engineering Co., Middlesex, UK) was used. The RSPaV-SY sequence was assigned the accession number AY368590 in GenBank.

The complete genome of RSPaV-SY was 8,725 nt long and had a genome organization similar to RSPaV with six ORFs ([12]; Fig. 1). The RSPaV-SY nucleotide sequence showed a genomic sequence identity of $77 \%$ to each of the previously published sequences of four other RSPaV isolates (RSPaV, RSPaV-1, RSPaV$\mathrm{BS}$, and RSPaV-SG1) [7, 8, 12]; these four isolates were more closely related to each other than to RSPaV-SY, sharing a genomic sequence identity varying from $83 \%$ between RSPaV-BS and RSPaV-SG1 [8] and 98\% between RSPaV and RSPaV-1 [7, 8]. The coat protein gene (ORF 5; see Fig. 1) of RSPaV-SY

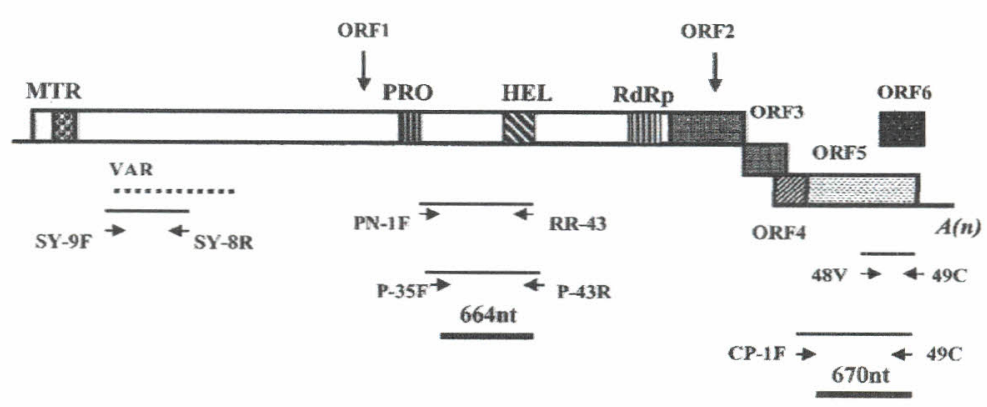

Fig. 1. Genome organization of the Rupestris stem pitting-associated virus, Syrah strain. Six open reading frames (ORF) were identified in the genome. The solid lines are the location of primers used in this report. Their respective sequences are given in Table 1. The thick lines show the size and location of the regions in the replicase and coat protein genes (ORFs 1 and 5) used for phylogenetic analysis. The broken line shows the location of the variable region (VAR) identified in the ORF1, which encodes for the replicase gene 

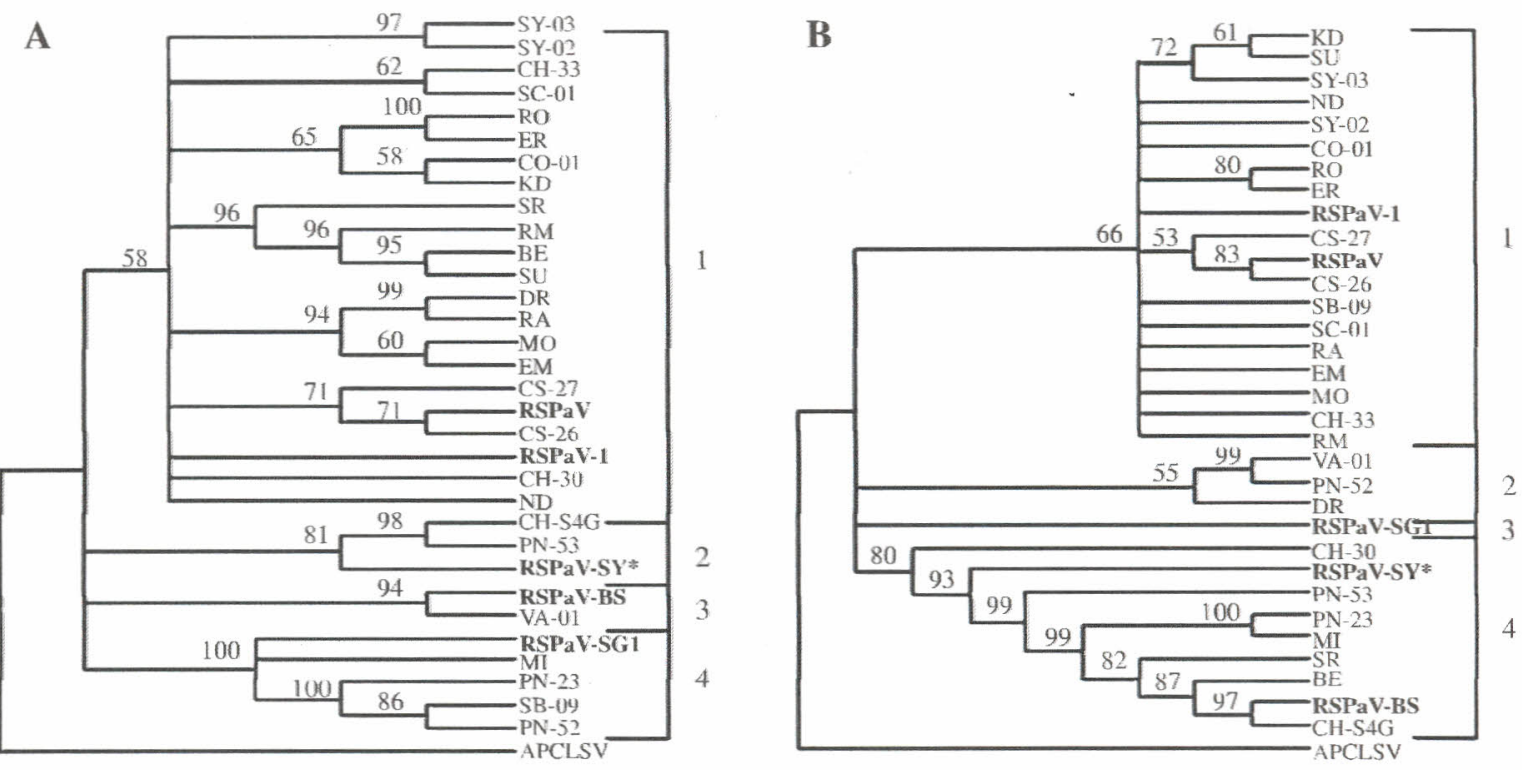

Fig. 2. Phylogenetic analysis showing the relationships among RSPaV-SY isolate (emboldened and marked with an asterisk) and other $31 \mathrm{RSPaV}$ isolates including the four isolates (emboldened) for which their full-length sequences are available in the database [RSPaV (AF026278); RSPaV-1 (AF057136); RSPaV-SG1 (AY881626) and RSPaV-BS (AY881627)]. For the comparison, fragments of the replicase gene were amplified by RT-PCR using primers P-35F/P-43R or PN-1F/RR-43, and the overlapping 664-nt fragments were used in the phylogenetic analysis of ORF 1 (A). For the coat protein analysis, fragments were obtained with primers RSP-49C and CP-1F (Table 1). However, due to difficulties in sequencing this product in some isolates, an internal forward primer, CP-3F, was designed based on sequences of several isolates and used on the remaining isolates. Complete sequences of the resulting products $(670 \mathrm{nt}$ in length) were utilized in the phylogenetic analysis of the coat protein (B). Apricot pseudo-chlorotic leaf spot virus [APCLSV (AY713379)] in the genus Trichovirus was used as an out group. The phylogenetic trees were generated by the Mega 2.1 program, with assistance of the Clustal X and Genedoc programs. Horizontal distances are proportional to sequence distances. The dendrogram was bootstrapped 1000 times. Bootstrap scores are on relevant horizontal branches. Branches with less than $50 \%$ bootstrap support are presented as polytomies. RSPaV isolates used in this investigation were from the following grape selections and the corresponding database accession numbers (replicase, coat protein) are presented in parenthesis: $D R=$ Damas Rose (AM180520, AM180426); $E R=$ Emile Royal (AM180539, AM180438); EM=Emperor (AM180532, AM180419); $R M=$ Red Malaga (AM180533, AM180424); $R A=$ Rangspray (AM180534, AM180422); $R O=$ Royal (AM180535, AM180427); $M I=$ Murma Isium (AM180536, AM180423); $K D=$ Kara Dzhidzhigi (AM180537, AM180437); ND= Noir D'automne (AM180531, AM180421); $B E=$ Bellino (AM180538, AM180420); $M O=$ Monukka (AM180540, AM180433); $S U=$ Sultana (AM180541, AM180443); $S R=$ Sultanina Rose (AM180542, AM180432); CS-26 and CS-27 = Cabernet Sauvignon-26 (AM180543, AM180440) and -27 (AM180521, AM180435); CH-30 and CH-33 = Chardonnay-30 (AM180522, AM180425) and -33 (AM180523, AM180439); PN-23, PN-52 and PN-53=Pinot Noir-23 (AM180519, AM180418), -52 (AM180529, AM180436) and -53 (AM180524, AM180430); SY-02 and SY-03 = Syrah-02 (AM180525,AM180442) and -03 (AM180518,AM180431); CO-OI= Coucoceira-01 (AM180526, AM180441); VA-01 = Valdiguie-01 (AM180527, AM180428); $S B-09=$ Sauvignon Blanc-09 (AM180528, AM180417); SC-01 = Schiopp.-01 (AM180530, AM180434); and $C H-S 4 G=$ Chardonnay-S4G (AM181038, AM180429) 
shared the highest nucleotide and amino acid identities ${ }^{\circ}(83-84 \%$ and $91-92 \%$, respectively) with other $\mathrm{RSPaV}$ sequences in the database $[7,8,12]$, while the replicase gene (ORF1) shared the least sequence identity $(75-76 \%$ and $85 \%$ at the nucleotide and amino acid levels, respectively). The most significant variation occurred in a region of 331 amino acid residues located between methyltransferase (MTR) and protease (PRO) conserved domains (See Fig. 1 - ORF1 dotted line). Amino acid sequence identity in this region was only $52-54 \%$ between RSPaV-SY and RSPaV/RSPaV-1, RSPaV-BS and RSPaV-SG1. The RSPaV-BS and RSPaVSG1 variants shared 74 and $73 \%$ amino acid identity with RSPaV, respectively, in this region of ORF1. In contrast to the replicase gene, the $5^{\prime}$ and $3^{\prime}$ untranslated regions of the RSPaV-SY and these other RSPaV isolates shared $91-96 \%$ and 91-92\% nucleotide identities, respectively. Further comparisons of the replicase gene between RSPaV-SY and the type virus of the genus Foveavirus, apple stem pitting virus (ASPV) [1] revealed 59\% nucleotide and $42 \%$ amino acid identities.

Phylogenetic analyses of $\sim 650$-nt regions of both the replicase and coat protein genes (Fig. 1) were performed to determine the relationships between RSPaVSY and 27 other RSPaV isolates from different grape varieties in a UC Davis collection (see legend Fig. 2). Analysis using the replicase gene sequence revealed that the RSPaV isolates segregated into four branches (Fig. 2A). The first branch was comprised of 22 isolates, including the previously sequenced RSPaV and RSPaV-1 isolates (which shared very close nucleotide identity of $98 \%$ of their complete genome). RSPaV-SY isolate, which has shown significant variability on the ORF1, clustered with only two other isolates, PN-53 and CH-S4G (branch 2). Branch 3 is formed by RSPaV-BS and VA-01 isolates, and RSPaV-SG1 with four other isolates was clustered on the fourth branch. The phylogenetic tree generated from the more conserved coat protein sequence differed to some extent in the groupings evident in the replicase sequence tree (Fig. 2B). Two main groups of isolates were identified in this analysis. One was formed by 17 isolates (branch 1) and the other by 9 isolates (branch 4). Most of the isolates in branch 1 were grouped together in both phylogenetic analyses. Branch 4 of this tree contained isolates from branches 2, 3 and 4 of the replicase gene tree. Overall, the RSPaVSY sequence clustered with few of the other isolates in the collection and, in this regard, the previously reported genomic sequences also represent different phylogenetic groupings. Within either of the phylogenetic trees, the clustering reflected neither the geographic regions of isolation nor the grape varieties from which the isolates were made.

To investigate incidence of RSPaV-SY isolate in commercial vineyards, by RT-PCR, two pairs of primers targeting two different genes were used (Fig. 1; Table 1). One set of primers, RSP $48 \mathrm{~V} / 49 \mathrm{C}$, was designed from a more conserved region (coat protein) and used as RSPaV-universal primers, which amplified a 331-bp fragment. The second pair, SY9F/SY8R, was designed from a more variable region (replicase gene) of the RSPaV-SY, which specifically detects this strain, and amplified a fragment of $628 \mathrm{bp}$. Among 383 plants tested, including 70 Syrah plants, $245(64 \%)$ tested positive using RSPaV-universal primers (48V/49C); 59 of 
Table 1. List of oligonucleotide PCR primers used in this study. Primers obtained from other sources are listed in the reference column

\begin{tabular}{|c|c|c|c|c|}
\hline & Sequence & $\begin{array}{l}\text { Location in } \\
\text { the genome }\end{array}$ & $\begin{array}{l}\text { Product } \\
\text { size }(n t)\end{array}$ & Reference \\
\hline $\begin{array}{l}48 \mathrm{~V} \\
49 \mathrm{C}\end{array}$ & $\begin{array}{l}\text { 5'AGCTGGGATTATAAGGGAGGT3' } \\
\text { 5'CCAGCCGTTCCACCACTAAT3' }\end{array}$ & $\begin{array}{l}8,180-8,200 \\
8,509-8,528\end{array}$ & 331 & unpublished \\
\hline $\begin{array}{l}P-35 F \\
P-43 R\end{array}$ & $\begin{array}{l}\text { 5'ATGGTTGCATGATCACAGCCA } 3^{\prime} \\
\text { 5'AGTGGCCAGCCTTCAATCC } 3^{\prime}\end{array}$ & $\begin{array}{l}3,545-3,566 \\
4,300-4,319\end{array}$ & 776 & this work \\
\hline $\begin{array}{l}\mathrm{PN}-1 \mathrm{~F} \\
\mathrm{RR}-43\end{array}$ & $\begin{array}{l}\text { 5'GATGGATACAAGTTACGGGC3' } \\
\text { 5'ACATCCCACCСТTCCTTCTT3' }\end{array}$ & $\begin{array}{l}3,442-3,462 \\
4,289-4,308\end{array}$ & 868 & this work \\
\hline $\begin{array}{l}\mathrm{CP}-1 \mathrm{~F} \\
49 \mathrm{C}\end{array}$ & $\begin{array}{l}\text { 5'GGTTTGAAGGCTTTAGGGGT3' } \\
\text { 5'CCAGCCGTTCCACCACTAAT3' }\end{array}$ & $\begin{array}{l}7,709-7,728 \\
8,506-8,526\end{array}$ & 817 & $\begin{array}{l}\text { this work } \\
\text { unpublished }\end{array}$ \\
\hline $\begin{array}{l}\text { SY-9F } \\
\text { SY-8R }\end{array}$ & $\begin{array}{l}\text { 5'AGGATTCCAAACTGTAGAGCAA3' } \\
\text { 5'TTGGTCGTCATCTTCCAGTT3' }\end{array}$ & $\begin{array}{l}2,083-2104 \\
2,689-2,710\end{array}$ & 628 & this work \\
\hline CP-3F & 5'TGAAGAAATTGATTATC $3^{\prime}$ & $7,741-7,757$ & - & this work \\
\hline
\end{tabular}

the positives were Syrah plants. Using the RSPaV-SY-specific primers (SY-9F/SY8R), $36(14.7 \%$ ) of the RSPaV-positive samples were also positive for RSPaV-SY, including 29 of the positive specimens from Syrah plants. Thus, roughly half of the diseased Syrah plants, but very few of the other infected grape varieties (7/186), were infected with the SY strain. To confirm the specificity of the RSPaV-SY primers, twenty of the amplicons generated by these primers were sequenced and found to share about $90 \%$ nucleotide identity to RSPaV-SY and about $73 \%$ to $\mathrm{RSPaV}$ sequences in the database. Among the Syrah specimens in the collection tested, four asymptomatic plants (without any canopy symptoms) were included in these assays and all of the four plants tested positive for the $48 \mathrm{~V} / 49 \mathrm{C}$ universal and one for RSPaV-SY (SY-9F/SY-8R) specific primers. Research is continuing to investigate the correlation between the virus and the disease.

\section{References}

1. Adams MJ, Antoniw JF, Bar-Joseph M, Brunt AA, Candresse T, Foster GD, Martelli GP, Milne RG, Fauquet CM (2004) The new plant virus family Flexiviridae and assessment of molecular criteria for species demarcation. Arch Virol 149: 1045-1060

2. Bovey R, Martelli GP (1992) Directory of major viruses and virus-like diseases of grapevine. Mediterranean Fruit Improvement Council \& International Council for the Study of Viruses and virus diseases of the Grapevine, Bary, Italy

3. Goheen AC (1988) Rupestris stem pitting. In: Pearson RC, Goheen AC (eds) Compendium of Grape diseases. American Phytopathological Society Press, St. Paul, p 53

4. Martelli GP (1993) Rugose wood complex. In: Martelli GP (ed), Graft-transmissible diseases of Grapevines: handbook for detection and diagnosis. Food and Agriculture Organization of the United Nations, Rome, pp 45-54

5. Martelli GP, Jelkmann W (1998) Foveavirus, a new plant virus genus. Arch Virol 143: 1245-1249 
6. Meng B, Credi R, Petrovic N, Tomazic I, Gonsalves D (2003) Antiserum to Recombinant virus coat protein detects Rupestris stem pitting associated virus in grapevines. Plant Dis $87: 515-520$

7. Meng B, Pang SZ, Forsline PL, McFerson JR, Gonsalves D (1998) Nucleotide sequence and Genome structure of grapevine Rupestris stem pitting associated virus-1 reveal similarities to Apple stem pitting virus. J Gen Virol 79: 2059-2069

8. Meng B, Caihong L, Wang W, Goszczynski D, Gonsalves D (2005) Complete genome sequences of two variants of Grapevine Rupestris stem pitting-associated virus and comparative analysis. J Gen Virol 86: 1555-1560

9. Rowhani A, Zhang YP, Chin J, Minafra A, Golino DA, Uyemoto JK (2000) Grapevine Rupestris stem pitting associated virus: population diversity, titer in the host, and possible transmission vector. Extended Abstracts $13^{\text {th }}$ Meeting, Adelaide, Australia, p 37

10. Stewart S, Nassuth A (2001) RT-PCR based detection of Rupestris stem pitting associated virus within field-grown grapevines throughout the year. Plant Dis 85: 617-620

11. Valverde RA, Nameth ST, Jordan RL (1990) Analysis of double-stranded RNA for plant virus diagnosis. Plant Dis 7: 225-258

12. Zhang YP, Uyemoto JK, Golino DA, Rowhani A (1998) Nucleotide sequence and RT-PCR detection of a virus associated with grapevine rupestris stem-pitting disease. Phytopathology 88: 1231-1237

13. Zhang YP, Rowhani A (2000) A strategy for rapid cDNA cloning from double-stranded RNA templates isolated from plants infected with RNA viruses by using Taq DNA polymerase. J Virol Methods 84: 59-63

Author's address: Dr. Adib Rowhani, Department of Plant Pathology, University of California, One Shields Avenue, Davis, CA 95616, U.S.A.; e-mail: akrowhani@ucdavis.edu

Verleger: Springer-Verlag GmbH, Sachsenplatz 4-6, 1201 Wien, Austria. - Herausgeber: Dr. M. H. V. Van Regenmortel, École Supérieure de Biotechnologie de Strasbourg (ESBS), Pare d'Innovation, Boulevard Sébastian Brandt, 67400 Illkirch, France. - Redaktion: Sachsenplatz 4-6, 1201 Wien, Austria. - Satz und Umbruch: Thomson Press (India) Ltd., Chennai, India. - Offsetdruck: Holzhausen Druck \& Medien GmbH, Holzhausenplatz 1, 1140 Wien, Austria. - Herstellungsort: Wien, Austria. - Printed in Austria. 